\author{
S.A. Nemkova ${ }^{1,2}$, O.I. Maslova ${ }^{1}$, G.A. Karkashadze ${ }^{1}$ \\ ${ }^{1}$ Scientific Center of Children's Health, Moscow, Russian Federation \\ ${ }^{2}$ Pirogov Russian National Medical Research University, Moscow, Russian Federation
}

\title{
PSYCHOLOGICAL ASPECTS OF COMPLEX MEDICAL AND SOCIAL REHABILITATION OF DISABLED CHILDREN WITH CEREBRAL PALSY
}

\section{Author affiliation:}

Nemkova Svetlana Aleksandrovna, PhD, professor at the department of neurology, neurosurgery and medical genetics of the pediatric faculty of Pirogov Russian National Research Medical University (RNRMU), senior research scientist at the cognitive pediatrics department of the RAMS SCCH research institute of preventive pediatrics and medical rehabilitation.

Address: 2/62, Lomonosovskii ave., Moscow, 119991, tel.: +7 (985) 921-64-18, e-mail: nemkova-sa@yandex.ru

Article received: 16.11.2012, accepted for publication: 24.03.2013

The article deals with psychological aspects of complex medical and social rehabilitation of disabled children with cerebral palsy in detail. Residual-organic cerebral insufficiency at cerebral palsy may be a basis for development of both cognitive disorders and psychogenic reactions, pathological personality formations due to the adverse psychosocial influences caused by disorders of motor and mental functions, which is necessary to take into consideration when conducting rehabilitation measures. The authors considered actual problems of diagnosing and treating the psychological disorders at cerebral palsy and suggested a system of complex mental pathology rehabilitation for this disease, which is aimed at correcting psychoemotional, cognitive and behavioral disorders and also restoring the social adaptation of children and adolescents with cerebral palsy.

Keywords: cerebral palsy, psychological disorders, rehabilitation.

According to the UN, $10 \%$ of total population of the Earth is disabled; this creates a range of ethical, social and economic issues, the resolution of which is one of the most important characteristics of modern society [1, 2]. More than 160,000 disabled children with impaired mental functions (including mental retardation, speech and other psychological disorders) now live in the Russian Federation, which is $32.8 \%$ of all disabled children; this predetermines high social significance of this issue $[1,2]$. In $60 \%$ of cases pediatric neurologic disability is 
connected with perinatal period pathology; 24\% of patients have cerebral palsy (CP) [3]. According to foreign authors, CP morbidity rate is 2.9-5 (2.5 at the average), in Russia - 2.2-3.3, in Moscow - 1.9 per 1,000 children [4-6]. In Moscow there are ca. 4,000 children and adolescents with cerebral palsy in whole; $80 \%$ of them have mental development disorders; this must be taken into account when planning medical and social rehabilitation of patients [7-9].

Formation of mental disorders at CP depends on etiological factors, ontogenesis period at the moment of factors' activity and sociopedagogic conditions, in which an ill child develops $[10,11]$. Residual-organic cerebral deficiency in children with cerebral palsy may serve as a basis for the development of cognitive pathology, psychogenic reactions and pathological personality formation due to unfavorable psychosocial phenomena caused by disability [10-12].

Studies of Russian psychologists show that children with cerebral palsy are characterized by delayed and uneven rate of mental development with disproportional formation of separate mental functions; this gives reason to speak about distinctive dysontogeny of mental development of cerebral-organic genesis. The main variants of anomalous development are:

- local dysontogenesis of separate higher mental functions (speech, spatial representations, different types of gnosis, praxis, attention, memory etc.);

- disturbed mental capacity;

- disturbed voluntary regulation of mental development;

- specific mental retardation characterized by a combination of disorders stated above with a steadily restricted knowledge and ideas about environment and specific peculiarities of mental activity, which is why the main syndromes in children with cerebral palsy are cerebrastenic syndrome (with intensely disturbed mental capacity), syndromes of local disorders of separate higher mental functions, disturbed development of emotional-volitional sphere [8, 1215].

Possible combinations of motor sphere and mental disorders at CP are numerous. Children are often able to take care of themselves, write and certain labor skills at spastic diplegia (tetraparesis affecting legs more than arms). Eye-mindedness deficiency (remember arrangement of rooms at school with difficulty, cannot draw) is noted together with satisfactory development of verbal thinking. Many of such children are able to study at regular schools [1, 8, 16]. Disturbed speech and calculation functions, retrography are often noted at hemiparetic form (pareses of one body side, more intense in the upper extremity) [8, 14, 17]. Hyperkinetic form is characterized by a triad: hyperkinesiae, hearing loss, intellectual deficiency (verbal thinking is especially affected due to speech disorders; eye-mindedness is preserved - children draw and construct successfully) $[8,18]$. 
According to most researchers, the most often noted disorders in children with cerebral palsy are disturbed spatial perception (up to 80\%), body scheme (up to 75\%), constructional activity (up to 60\%) and kinesthetic praxis (up to 60\%) [1, 8, 19, 20]. The main types of intellectual development pathology at CP are mental retardation of different severity level and borderline forms of intellectual deficiency characterized by milder and to a large degree reversible cognitive activity disorders $[1,8,14,19,20]$.

We studied the spread and structure of mental development disorders in $916 \mathrm{CP}$ patients (1-18 years of age) on the basis of the FSBI “Scientific Center of Children's Health"; we revealed that the closest to norm intellectual development is noted in $50 \%$ of children with hemiparetic form, in 33\% - with spastic diplegia, in 23\% - with hyperkinetic form, in 4\% - with atonic-astatic and in 3\% of patients with double hemiplegia. Mental retardation was observed in $27 \%$ of children with atonic-astatic form, in 25\% - with hemiparetic form, in 19\% - with spastic diplegia, in 16\% - with hyperkinetic disease form and in 14\% of patients with double hemiplegia. Mental retardation of different severity degree was noted in $83 \%$ of patients with double hemiplegia, in $65 \%$ of patients with atonic-astatic form, in $61 \%$ - with hyperkinetic form and in $48 \%$ - with spastic diplegia [1, 21].

Thus, intellectual deficiency frequency and structure analysis in patients with various CP forms shows that intellectual disorders are the least observed at hemiparetic disease form and spastic diplegia (borderline disorders and mild mental retardation prevail there) and the most observed at double hemiplegia (prevalence of moderate and severe mental retardation forms).

Borderline residual-organic neuropsychic disorders (in 2/3 of patients) and various psychogenic pathologic personality formation variants (deficiency type) (in 1/3 of patients) go closely together with intellectual-mnestic disorders in children with cerebral palsy; they often are the main disease symptoms and require differentiated medical-correctional work, as they may go through compensation-decompensation stages during rehabilitation and largely determine its effectiveness [22-24].

Borderline residual-organic disorders are conditions resulting from cerebral affection on some ontogenesis stage, including perinatal period; in children with CP these are cerebrastenic, neurosis-like and psychopathy-like syndromes. These disorders most often prevail and preschool and early school age, although they may be noted throughout all life [15, 24].

Cerebrastenic syndrome takes the leading position in clinical presentation of CP patients, considerably complicating behavior of both diagnostic and correctional measures. Its characteristic features are working capacity reduction (organic type), attention exhaustion, memorization weakness and affective disorders. In CP patients it is closely associated with motor effect peculiarities and is often accompanied by intense hypertensive, vegetovascular and 
vestibular disorders; moreover, it has different course specificity according to the disease form. Thus, spastic diplegia is primarily associated with asthenic-adynamic cerebrastenic syndrome, hemiparetic and hyperkinetic forms - with asthenic-hyperdynamic variant. Decompensation of cerebrastenic manifestations at rehabilitation is usually connected with somatic diseases, which patients had at inpatient hospital, orthopedic-surgical interventions, or in case of insufficiently effectively planned individual rehabilitation program (excessively stressful). It should be remembered that in $\mathrm{CP}$ patients there is an interconnection of cerebrastenic manifestations and emotional reactions with motor pathology; this reflects on the muscular tone condition. In case patients with spastic diplegia are tired (usually in the afternoon), muscular tone may increase; in case patients with hyperkinetic disease form are tired, they may experience aggravated coordination of movements, intensification of hyperkinesiae up to the level of "movement storm” with intense vasovegetative symptoms [8, 11, 23].

Neurosis-like syndrome at CP has its own specificity depending on the disease form: spastic diplegia is most often associated with phobic variant in the form of various fears, hyperkinetic form - with hysteria-like variant. Phobias are usually connected with motor impairment (fears of falling, moving, street, height) and cannot be resolved; thus, even when children have mastered walking skill, they often move only when someone stands by them; this hampers the locomotive function automation development [8]. Children with hyperkinesiae, despite frequent falls and hurts, are disinhibited in terms of motion, impulsive, euphoric; neuroses in the form of stammering and enuresis are the most often noted at hemiparetic form. Neurosis-like syndrome at CP is also connected with motor impairment: psychomotor reactions resembling "movement storm" with muscular tone intensification, non-reduced tonic reflexes, hyperkinesiae, vegetovascular manifestations (up to shock manifestations, especially at small age) may be noted in patients with hyperkinetic form at change of scene or separation from mother at inpatient hospital; this leads to child's deadaptation, distorts clinical presentation and considerably hampers rehabilitation. On the contrary, patients with spastic diplegia at deadaptation are characterized by motor retardation, apathy, rejection from food and regular emesis. Mere appearance of the mother often cuts off these pathological symptoms; this predetermines her being with a child at least in the first days at inpatient hospital. Decompensation of neurosis-like disorders in children with CP may also appear at fatigue, somatic ill-being, overheat, atmospheric pressure change and at the end of rehabilitation course or school year $[8,11]$.

Hysteria-like neurotic disorders in children with CP may appear without cause, without aspiration for attracting attention (as at hysteric reactions in healthy children); as a rule, they appear at overfatigue, at the end of day or week; this determines the need in selecting adequate 
stress during rehabilitation. Clinically, reactions manifest themselves in the form of affectivemotor or affective-vegetative fits with shouts, body flexure, intensification of hyperkinesiae, tonic reflexes, consciousness narrowing (it is difficult to attract attention of such a child), which often turn into compulsive weeping [8].

Psychopathy-like syndrome takes its course in CP patients in the form of mental instability and increased emotional excitability (impulsive-epileptoid, hysteria-excitable) with disturbance of drive. Clinically, it manifests itself with volitional sphere underdevelopment, prevalence of enjoyment motives, game and entertainment appeal; this leads to disorganization and low working capacity. These children are often considered disorganizers and offenders. Decomposition is usually connected with biological factors (overfatigue, somatogenies) and is rarer caused by psychogenic causes; it is accompanied by aggravation of not only psychopathologic, but also motor disturbances (tone intensification, hyperkinesiae). Anosognosic type of reaction to the disease is peculiar to patients (especially at left hemiparetic CP form) unacceptance, ignoring of defect; this considerably complicates rehabilitation $[1,8,25]$.

Apart from medicamental correction, protective regimen and sufficient sleep are important for treating neurotic reaction; it is necessary to avoid overfatigue (1-2-day-long breaks in rehabilitation are sometimes recommended) and overprotective miseducation and conduct psychotherapy. It is necessary to conduct psychotherapeutic measures aimed at teaching patients muscular relaxation as the main component of autogenic training [8].

Apart from borderline mental disorders, CP is often characterized by pathological personality traits (deficiency type), when impact of social factors caused by incapacitation of children and causing psychologic traumatic experience inevitably adds to rough organic pathology [26-28]. Such unfavorable factors are:

- experiencing unfriendly attitude of peers, excessive attention of the people around;

- hospitalism phenomenon (patients stay at hospitals and sanatoria, isolated from society and peers, for long periods of time);

- separation from mother or incomplete family (in $25-30 \%$ of cases);

- mental traumatism caused by medical procedures (operations) due to lack of correspondence between child's hope of quick recovery and need in prolonged rehabilitation;

- difficulties in education caused by paralyses, hyperkinesiae and spatial disorders;

- sensory deprivations due to often concurrent visual and hearing impairments;

- overprotective miseducation (leads to formation of egocentrism, spoilage, shyness and emotional immaturity) [25-28]. 
It is known that psychological compensation may take 2 ways: the first of them is caused by influence of a socially favorable environment, which smoothes the main psychopathic features out; the second is about generating secondary behavioral traits, which efface the leading symptom complex, and is connected with internal personality resources, which allow finding ways of adapting to the environment. The second way is observed more often; hyper- and pseudocompensation phenomena are possible, when new personality traits themselves hamper full-scale adaptation to environment [15, 21]. Decompensation manifests itself with noticeable aggravation of all personality-inherent traits; it is also characterized by temporary or prolonged reduction or loss of the available social adaptation. Compensation and decompensation interchange reflecting intensity of pathological traits and ability to adapt. Conducting rehabilitation of children with limited capabilities it is necessary to take into account that psychologic traumatic experience that takes part in the appearance of decompensation is different in case of different personality disorders: one and the same psychologic traumatic experience for some patients may be significant, for some it may be mild or even neutral [15, 21].

Due to the fact the disabled children with $\mathrm{CP}$ endure inferiority, psychogenic reactions appear; in case of decompensation, they form in 2 directions: passive-defensive and aggressiveprotective [8, 27]. Psychogenic personality alterations are clearer observed in adolescents and often prevail over the psychoorganic ones, which endure involution in the process of age dynamics and treatment. In whole, psychogenic pathological personality formation is observed in children with spastic diplegia, rarer - at other forms; however, psychogenies start appearing faster in case patients' condition is aggravated by visual or hearing defects. To understand this problem, some researchers use Jung's concept of extra- and introverted personalities: children with spastic diplegia are more often characterized by introverted behavioral traits: fearfulness, susceptibility to various fears and love to increased attention which guarantees safety. Children with hyperkinesiae are characterized by extraverted traits: commutability, high excitability, quick temper and emotional instability [8, 27, 29].

Various mental infantilism variants prevail among the personality maldevelopment types; their main sign is the underdevelopment of voluntary regulation of behavior and higher forms of volitional activity; all 3 variants of complicated mental infantilism are noted in CP patients [12]:

1) neuropathic (a combination of mental infantilism with neuropathic manifestations);

2) cerebrastenic (emotional-volitional immaturity signs combine with increased emotional excitability, disturbed memory, attention and mental working capacity); 
3) organic (combination of emotional-volitional sphere immaturity with intellectual activity disorders in the form of inertness, stiffness of mental processes, low level of generalization operations).

Mental infantilism manifestations characterize almost all children with cerebral palsy: age-incoherent childishness and spontaneity traits; game appeal and tendency to fantasize and dream are prevalent activities. Fearfulness and increased "mental inhibition” in unfamiliar environment peculiar to children cerebral palsy register in them for long; this has significant influence on the education process $[8,30]$.

Apart from various manifestations of mental infantilism, a range of researchers note the occurrence of psychasthenic, asthenic and autistic personality formation variants in children with CP $[5,17,25]$.

Prolonged clinical-dynamic observation allowed suggesting the following typology of psychogenic pathologic personality formation in children and adolescents with cerebral palsy [8, 23, 26]:

1. Asthenic-neurotic type is characterized by increased tenderness, touchiness, intolerance to slightest life and educational difficulties, inferiority complex with the formation of passive-defensive reactions, rarer - by stammering and enuresis, fear of falling, moving, heights; affective fluctuations, especially in adolescence, with a tendency to anxious and depressive conditions and sometimes suicide attempts. It is more often observed in patients with pronounced motor impairment, unstable gait, patients who strongly depend on the people around. Children endure medical examination, injections and other procedures painfully; this is accompanied by intense vegetovascular reactions; they get used to inpatient hospital conditions with difficulty, react to separation from mother by adynamy, tearfulness and rejection from food. Insufficient ability to sustained physical and intellectual stress is noted. Positive features are purposefulness and interest in completing tasks; this provides for the compensation asthenic manifestations and is a basis for rehabilitation.

2. Pseudoautistic type is formed, as a rule, in immobilized patients with severe motor impairment concurrent with speech disorders; this causes child's social deprivation and manifests itself with tendency to unsociability, passiveness, solitude, introspection, fantasies, which often have hypercompensatory character. Patients often write poems and keep diaries; some girls collect photos of ballerinas. Children slowly get used to new environment when admitted to inpatient hospitals and quickly get tired at correctional studies. Defect's realization and orientation at its correction is observed in this group's children and adolescents even before preschool age. This type of patients belongs to the increased risk group in terms of tendency to suicide. 
3. Affective-excitable type is characterized by increased emotional excitability, aggressive fits, rudeness, pugnacity, protest and rejection reactions and imitation of negative behavior of the people around, especially at chronic psychologic traumatic experience. It is more often observed in case of unfavorable life and upbringing conditions and genetic predisposition. It is peculiar to children with mildly pronounced motor impairment, as a rule, with hemiparetic CP form. Compensation is possible when the psychologic traumatic situation is resolved and child escapes from the negative influence of family and people around, when adequate professional interests form.

4. Unstable variant is, as a rule, formed in adolescents; volitional activity underdevelopment, suggestibility, unconcern, instability of intentions and actions, tendency to constant self-hyperesteem, change of impressions and superficiality of knowledge and judgments is noted at that. It is primarily observed at hemiparetic and hyperkinetic CP forms. Restlessness, mild satiation in the process of education, prevalence of gaming motives often lead to low school performance, which is why it is important to create interest in doing work in these children. Imitation reactions are observed in children who receive education in unfavorable conditions; this may lead to violation of study regimen, evasion and leaving of classes and asocial lifestyle. Regulated inpatient hospital conditions temporarily compensate unstable personality features; however, decompensation easily takes place in the future, as these children are very susceptible to negative influence. Preventive measures should be aimed at normalization of social conditions, working out of volitional effort, rehabilitation mood with bright emotional interest.

5. Hysterical variant is characterized by egocentrism, capriciousness, stubbornness and excessive claims of increased attention. Miseducation (“family idol” type) has special significance in the formation of this type. Disobedience, unwillingness to work and regimen disorders are often noted. Decompensation may appear both at psychologic traumatic experience (in this case psychogenic reactions often have acute character, with motor excitability, increase in tone, hyperkinesiae and synkineses, vegetovascular disorders, demonstrative suicidal tendencies) and satiation by routine everyday life, lack of emotionally saturated tasks and realization of an intention to be the first. Relative compensation appears together with the improvement of motor functions; adaptation and relationships with the people around improve in this case. When planning rehabilitation, it is necessary to offer a child emotionally saturated tasks (children willingly perform prestigious tasks, play in school theater, love bright clothes and music), combine exactingness and encouragement of children, use collective psychotherapy to overcome egocentrism and labor therapy with frequent transfer to different activity types. Family psychotherapy should be planned with an explanation or irrational overprotective education. 
6. Disproportional type is characterized by combination of immaturity and partial mental acceleration features; overprotective education in the conditions of shortage of communication and lack of experience is conductive of it; at the same time children are wellread, excessively serious, but often are uncritical and underestimate situations.

Studying the main personality features of cerebral palsy patients using pediatric variant of the Cattell personality questionnaire [19], it was revealed that the dominant personality features of patients were increased anxiety, lack of self-confidence, tendency to regular doubts and fears, constant tension, general irritability, dissatisfaction with oneself and people around, increased responsibility and control feeling. At the same time, they were emotionally unstable, increasingly psychologically vulnerable and had reduced tolerance to psychological stress. Occurrence of relatively limited knowledge and concrete thinking prevalence in some patients attracted attention. These data indicate that latent tendency to gradual formation of obvious personality alterations still took place even in those CP patients, in whom they could not be identified clinically-psychopathologically [19].

Different personality traits of CP patients cause different forms of overcoming disease and compensating for defects [8, 31-33].

There are data confirming the influence of psychological peculiarities of children with CP on the effectiveness of orthopedic-surgical treatment [22]. Children, distinguishable by the increased dependence on other people in resolving conflicts and painful fixation on their defects, endured post-operative period better; however, despite successful surgical interventions, their motor activity was considerably reduced, phobias and dependence were observed. Children with self-accusing direction of reactions (shy and diffident) endured post-operative period worse; however, they got involved in rehabilitation measures faster and were more active than the previous group's patients, which is why long-term results were better in them. Children with increased activity in resolving conflict situations and aggressive attitudes complained of pain and claimed undivided attention in the post-operative period, but they were much more active than children of other groups, new motor stereotypes formed in them faster; this provided for better social adaptation and independence.

It should be noted that rehabilitation measures may themselves cause compensationdecompensation conditions and determine children's mental status alterations.

The study of how surgical treatment influences psychological peculiarities of children with CP [11] revealed that no intense psychogenic reactions were noted in most children admitted to the inpatient hospital; confusion and asthenophobic disorders with the increase in muscular tone and hyperkinesiae were noted only in some of them; they could be cut off by prescribing tranquilizers. However, patients eagerly anticipated operation, as they had seen how 
other children improved after operative interventions. 3 time periods of forming neuropsychic disorders seen as decompensation caused by somatopsychic factor were observed in the postoperative period:

1) asthenodynamic (2-6 days) period was characterized by increase in vasovegetative disorders and hypertensive syndrome and imbalance of hypothalamic syndrome;

2) period of increased cerebrastenic symptomatology (2-3 weeks) was characterized by irritable weakness, hyperesthesia, emotional lability, depressive reactions, especially in younger children impatiently anticipating direct results of the operation and hardly enduring pain and immobility caused by plaster bandages; moreover, all previous personality traits were becoming accentuated in this period: children with asthenoneurotic disorders were becoming shier and involved into active rehabilitation later; sthenic patients endured post-operative period better and were less depression-prone. Even adolescents with pathological personality development (excitable type) displayed self-control and were getting actively involved in rehabilitation. Patients with hysteric traits sharply reacted to pain; their complaints were exaggerated;

3) 1-1.5-month-long involution period of cerebrastenic and intellectual-mnestic disorders associated with the operation.

In whole, long-term results of surgical correction influence on the forming personality's traits may in most cases be assessed as conditions of relative compensation of pathological features in view of psychogenic factor action, anxiety and cosmetic defect reduction with the extension of social network and improvement of social adaptation [11].

In order to assess dynamics of syndromes of mental disorders in children with cerebral palsy in the complex rehabilitation process, we examined 198 patients [1, 6, 21].

Assessing contact degree of patients (unchanged, reduced, without distance, lacks) we revealed that the contact preserved in 1/3 of children, without sense of distance - in 19\% (more often at hyperkinetic form); contact lacked in $11.2 \%$ of children (primarily at double hemiplegia). Improvement was noted in $84.2 \%$ of children after complex treatment. Absentmindedness is the highest at hyperkinetic form and spastic diplegia (88.6\%). As long as neither manifestation of higher mental functions may be considered in isolation, we studied emotional sphere peculiarities of children with CP. Their impoverishment prevailed in the structure of emotions - in 20.7\%; in the setting of their insufficient adequacy - in 19\%. The more preserved the intellect was, the more dominant emotional lability and euphoria were becoming with age. Improvement was noted in $90 \%$ of children in the setting of treatment.

Disinhibited behavior was observed in $42 \%$ of children, especially at superficial mental defects in the setting of hypersympathicotonia. Behavior was situation-adequate in $1 / 3$ of 
children. Improvement of behavioral reactions with age was noted in $74 \%$ of children with cerebral palsy.

Analysis of skills showed that gaming skills were reduced in $65 \%$ of children with cerebral palsy due to a range of reasons: psychoverbal retardation, intense motor impairment and encephalasthenia. Self-service skills were lacking in $40 \%$ of children, only $20 \%$ could dress themselves, ca. $1 / 4$ of children could not toilet without assistance even at an older age. Positive dynamics at education was observed in $88 \%$ of patients.

Only $62 \%$ of patients could draw after long-term rehabilitation, write $-64 \%$; both quality and spelling depended on the condition of motor and intellectual spheres.

Intellectual activity productivity reduction was noted in 50\% of patients; half of children were not improving in the setting of treatment; this complicated the educational process.

System of complex rehabilitation of mental disorders at CP should include medical, psychological-pedagogical and social rehabilitation and predetermines measures aimed at forming mental functions and skills allowing a child to learn and perform different social roles, to adapt in society, i.e. aimed at recovering medical and psychological mechanisms of social integration [34-39].

The following issues are the most relevant when rendering psychological-pedagogical help to children with CP:

1) more than a half of children with cerebral palsy contact with pedagogues and psychologists only at impatient hospitals;

2) tactics of treating cognitive-behavioral disorders in children with CP often adds up to maximal use of drug therapy and insufficient use of psychological-pedagogical correction methods;

3) most techniques developed for schools and kindergartens cannot be used in clinics for children with cerebral palsy unadapted due the limitation of patients' terms;

4) standard rehabilitation programs and scheme of classes, on which a pedagoguepsychologist could have relied in interaction with other participants of medical process (doctors, speech pathologists) to plan effective correctional work for each patients taking into consideration complicated structure of a defect and variety of combinations of motor, sensory, cognitive and behavioral sphere disorders are required;

5) preparation system and normative activity basis of clinical psychologists and pedagogues/speech therapists working at inpatient hospitals with children with CP has not been developed yet;

6) children are cut off the special education system and cannot study programs of schools of VI-VIII types due to specificity of medical institutions; 
7) despite the fact that most patients with cerebral palsy are educable (20\% of them may study the regular school's program), local educational institutions do not have conditions corresponding to these children's motor development and teachers there do not know methods of forming school skills in case of severe affection of arms and speech-motor apparatus;

8) if children attend comprehensive or specialized institutions (including residential schools for children with CP), parents reject from inpatient treatment so that they children do not underperform at school;

9) tactics of teaching parents children's medical rehabilitation methods in the aspect of age given their psychological peculiarities, affection level and nervous system's damage degree, age dynamics of disease symptoms, prognosis of child's development at different disease forms, behavioral disorder and intellectual deficiency.

The main principles of medical-psychological-pedagogic correction in CP patients should be unity of diagnostics and correction, early beginning and complex character of correctional work (with combined correction of motor, sensory, cognitive and mental disorders), organization of work within the leading activity given child's age peculiarities, coherent principle, personcentered approach, dynamic observation principle in the process of child's development and unity of correctional work with children and people around them (family, society) [1, 6, 8, 37, 40].

Reasonability of rehabilitation, its priority spheres, optimal methodological techniques are first of all determined by which mental activity spheres appeared damaged and which mental functions should be restored and developed in the first place. Realization of an individual rehabilitation program of mental disorders in CP patients is provided by the interaction system of different specialists designed to organize work rationally. Medical-psychological-pedagogic influence should be conducted in complex by a doctor, pedagogue-psychologist and speech therapist. It is necessary to combine various types and forms of correctional-pedagogic work (individual, subgroup and frontal) flexibly.

When planning CP rehabilitation program, we must take into consideration patient's personality peculiarities, structure of psychological disorders and mechanisms of compensating for them. Variety of psychological disorders in children with CP requires using the whole range of possibilities given by complex psychological-pedagogic influence: correctional pedagogics, speech pathology correction conductive pedagogics, Montessori system, psychotherapy (including family psychotherapy) methods, adequate choice of an educational institution and labor therapy [1, 2, 6, 23].

Psychological rehabilitation involves a range of directions [21, 24, 28, 32]: 
1. Correction of ideas on the internal disease presentation, its prognosis, life hazard, patient's position in social micro- and macrostructure; determination of anxiety scale.

2. Deontological situation correction.

3. Correction of motivation to health, rehabilitation, labor and social activity.

4. Correction of the relationship system of the patient's personality (medical personnel, family, colleagues, friends etc.).

5. Psychological activation and patient's behavior normalization according to the adequate rehabilitation prospect. CP patients’ psychological rehabilitation given their age and intellectual capabilities may involve many directions:

- individual, or person-centered (constructive), psychotherapy;

- group pathogenetic therapy;

- autogenic training;

- psychological climate creation;

- bibliotherapy, culturological measures;

- psychotherapeutic rehabilitation orientation;

- labor therapy;

- education and use of modern computer means and technologies;

- psychogymnastics using eurhythmics, pantomime and dance;

- organization of a club for ex-patients;

- psychotherapeutic orientation of sport games;

- family and society psychotherapy;

- teaching workers of social and services peculiarities of working with disabled people in society;

- creation of an urban environment adapted for use by disabled people.

These measures are necessary for disabled children to get to know new society, which also is their lifestyle.

The structure of psychotherapeutic measures should include the pathological personality development formation prevention given intellectual deficiency, as clinical symptoms of mental retardation are polymorphic in character and intensity degree of psychopathological manifestations [15, 21, 24].

The determining factor of the psychological-pedagogic rehabilitation success is the ill child's family participation. Due to the huge role family plays in child's personality development processes, it is necessary to organize the environment (household, leisure, upbringing) in a way that would maximally stimulate this development and smooth out the disease's negative 
influence on the child's mental condition. Parents are the important participants of psychological-pedagogic work organized with children, especially if they do not attend an educational institution for some reason [21, 41, 42].

The task of parents is to help children in complex conditions of the disease to unlock their natural development potential, to form compensatory capabilities, to prepare for school and to maximally adapt them to being in groups of children and to independent life in perspective sometimes it may be simple, though useful professional activity. It is family, parents that is the main source ill children may derive strength and energy from. Family (most often - mother) can give children prerequisites of realization and further independent use of all achievements and skills of the humankind.

However, communication of parents with their disabled children often has peculiarities that hamper correct and harmonic child's personality development and considerably hamper effective psychological-pedagogic correction; relationship with parents may in this case be an additional incapacitating factor in child's mental development.

We can point out several behavior models of parental attitude to disabled children [41, 42]:

- Unconditional acceptance of children and their defects: objective reality realization by a parent and adequate evaluation of children (a parent does not have feelings of guilt or child's reprobation; the main principle being "the achievement of as much as possible”; age and development level adequate games are demanded from children; there is belief in self and child's capabilities). This upbringing type is the most favorable for achieving positive rehabilitation results.

- Defect denial reaction of parents is characterized by defect unacceptance and nonacknowledgment of restrictions (inadequate perception of child's condition); ambitious parents claim that child's activity is highly successful. This upbringing type may have positive influence in case a child has strong nervous system type, as parental attitude stimulates tensions and fight with the ailment followed by development. On the contrary, if a child has weak nervous system type, child's personality sphere may get disturbed, as nervous strain increases. Defect denial reaction requires certain psychocorrectional work with ill child's parents.

- Excessively protective/overprotective reaction: manifests itself with excessive care and protection of children against all real and imaginary dangers, when parents do too much work for their children; this leads to infantilism and symbiotic attachment to mother. 
- Latent renunciation and reprobation of defect: child's defect is seen as shame, negative attitude or aversion for a child hidden behind excessively protective and attentive upbringing is present (maximal satisfaction of physical and ignoring of emotional needs). These parents are characterized by pedantic aspiration for looking like model parents.

- Open renunciation, reprobation: realization of hostile feeling to a child by parents; this creates feeling of guilt and causes defense reactions in the form of accusing doctors, teachers and society of prejudice forming towards an ill child.

It is known that the basis of constructive attitude towards children and their defects is parents' ability to accept their children unconditionally. Other attitude types negatively influence children's personality formation, detain and hamper their development and reduce effectiveness of rehabilitation measures. Reactions of defect denial, latent renunciation and overprotection indicate relative acceptance of child's individual peculiarities by parents; its counterpart is reprobation, i.e. overprotection, and, thus, emotional deprivation. The severer the defect, the more possible are reprobation reactions in parents. Thus, child's objective psychophysical peculiarities may influence the character of child-parents relationship together with personality features of parents themselves [33].

That is why it is important to timely reveal and correct wrong attitude to a child; to do this it is necessary to conduct complete examination of child-parents relationship, including family upbringing style identification, study of parents' motivation sphere and identification of their expectations. In case high anxiety of parents, insufficiently effective upbringing style and thus excessive demands on a child are revealed, correctional work including the use of group trainings on overcoming anxiety and increasing parental competence are conducted.

Work with families should include the following main child's personality development directions [21, 36, 41, 42]:

- $\quad$ maximally possible development of motor functions, self-service skills, hygiene, movement and labor;

- development of speech, gross and fine motor skills, senses, intellectual development given individual physical and mental capabilities of each child, ideas about the environment;

- $\quad$ formation of an active life stance;

- $\quad$ preparation to school;

- $\quad$ early professional orientation, selection of the further activity sphere;

- $\quad$ psychological preparation and realization of one’s future position in life, value of one’s personality, guarantee of social realization of one’s relevance. 
Initially, it is necessary for parents to know children's disease peculiarities, their development capabilities and prospects, competently organize their social and living conditions, including day regimen, systematic purposeful correctional exercises, form adequate self-esteem, right attitude to the defect and develop indispensable volitional qualities in order to create favorable upbringing conditions in a family. In order to do this, they should involve gaming and feasible labor activity in child's life, actively involve a child into family daily life [21, 36].

Psychosocial rehabilitation of an ill child's family is a multidimensional and extremely important work. Mode of behavior of doctors and pedagogues-psychologists is as individual as families they work with, however, there also are common principles [21]:

- early and complete information on diagnosis and prognosis;

- practical recommendations;

- home visits for withdrawing emotional problems;

- contacts and psychological climate in a family and its correction.

According to our data, ca. half of mothers of disabled children feel unhappy; they are tense, irritated, hypoemotional and lack self-confidence. $61 \%$ of parents of children with CP constantly feel anxious, $71 \%$ note the occasionally arising feeling of panic. Both internal (family resources (due to financial stress)) and external circumstances (disemployment, work not associated with the received education) change when there is a chronically ill child in a family, which is why family discord and physical restrictions develop (restriction of leisure and parents' rest, change of personal life and often of family status, as more than a half of families with a disabled child are incomplete).

According to the polling results, 9\% of parents of children with cerebral palsy do not allocate any time for rest and entertainment; $51 \%$ do not allocate enough time for that. 1/3 of parents assessed their health as good, other - as satisfactory; 52\% of parents had chronic diseases.

Depression arises in more than a half of parents of children with cerebral palsy due to many reasons. Wish for having children is multidimensional - love, hope for the next family generation, transfer of culture, synthesis of 2 people; disabled children sometimes do not legitimate these expectations. With age, an ill child often has aggravation of an impaired function instead of compensation; this causes the change in parents' evaluation of their child, which is not always adequate and for the better. It should be noted that motivation of parents has a defensive character; sometimes they are worried about losing social status or unaesthetic character of child's defect. Still, a specialist should inform parents about their child's diagnosis fairly, should not hide difficulties or dramatize them. Optimistic orientation of parents should be supported, but it is unethical to employ consolation without explaining the situation. It is 
reasonable to talk not about complete recovery, but adaptation, and talk about it in plain language, conducting terminological screening. Most parents want to have complete information on child's disease and treatment methods; in the future they become the best "psychologistspediatricians", as the guarantee of successful treatment lies in partnership. Psychoemotional support of family, positive evaluation of work of parents, relatives and their encouragement are necessary.

Analyzing why parents of children with cerebral palsy applied to the FSBI "SCCH" polyclinic, we revealed that $16.4 \%$ applied for specifying diagnosis (diagnosis was confirmed in $75.4 \%$ ), $81.9 \%$ - for the prescription of adequate treatment and only $7 \%$ - for medical-genetic consultation (severer disease forms). Polling of parents revealed that children of 0-1 years of age were set correct diagnosis in $39 \%$ of cases, children of $1-2$ years of age - in $40 \%$ of cases, children of 2-3 years of age - in 13\% of cases, children of 3-4 years of age - in $4 \%$ of cases, children of 4-5 years of age - in 2\% of cases, children of 5-6 years of age - in 2\% of cases. Ca. half of parents were dissatisfied with the way doctors informed them about their children's disease.

47.2\% of parents assessed their children's intellect as normal, $13.9 \%$ - as close to normal, i.e. explainable overestimation took place: almost all children with cerebral palsies have positive dynamics in the form of acquiring motor functions, speech development and self-service skills in the setting of development; thus, psychic defects seem to level. $44 \%$ of parents believed in the possibility of child's complete recovery as a result of rehabilitation, $42 \%$ believed in partial recovery and $14 \%$ believed only in the improvement of skills. $82 \%$ of parents actively looked for new drugs and methods treating CP, however, this activity would fade with the lapse of time. 1/3 of parents had conflicts with their attending doctor about the conducted treatment due to (according to parents) doctor's heavy lead - 20\%; doctor's personality features - 20\%; poor organization of work at the medical institution - 24\%; child's personality peculiarities - 36\%. $37 \%$ of parents experienced difficulties in establishing contact with doctors throughout life. According to parents, the determining factors in establishing psychological contact with doctors are: $23 \%$ of respondents - severity of child's disease; $19 \%$ - child's psychological and personality peculiarities, 36\% - doctor's psychological and personality features; 18\% - doctor’s disinterest in cooperation; $4 \%$ - insufficient qualification of a doctor.

Effectiveness of each rehabilitation stage directly depends on the ability of parents to secure the obtained results both at inpatient hospital and at home, and sometimes even to conduct certain stages of correctional program themselves, by agreement with pedagogue-psychologist and doctors. Our data state that $86 \%$ of parents were given recommendations on using 
rehabilitation techniques at home by inpatient hospitals; $81 \%$ performed them in full, $5 \%$ partially.

Parents should be active participants of the rehabilitation process, which is why a pedagogue-psychologist should explain parents the gist of children's intellectual, speech and emotional problems; help to find optimal approach to children and to exercises with them; explain the current work stage; demonstrate forms of work during consultation exercises; help to choose the necessary educational and methodological materials; clearly register and discuss positive dynamics in children's development, both spontaneous and resulting from exercises; actively involved family in exercises; offer "homework" both during hospital stay and during breaks in inpatient treatment.

Maximal frequency and duration of inpatient psychological-pedagogic correction courses are necessary when [36]:

- previous psychological-pedagogic influence was effective and positive dynamics was observed;

- structure and degree of child's motor and mental sphere affection is such that dynamics of their development fatefully influences prognosis of the patient's social adaptation;

- adequate domiciliary psychological-pedagogic help is not possible.

At the same time clinical experience shows that prolonged, months-long inpatient hospital stay may cause decompensation (so called hospitalism) and aggravate child's inertness, dependency, depression, suicidal tendencies due to social deprivation.

Such an issue of children's disability as suicide should not be overlooked, especially with adolescents who acutely suffer from their physical inferiority and tend to autoaggressive actions [8, 28, 32]. In whole, suicidal behavior of children and adolescents is characterized by the following features: firstly, insufficiently adequate evaluation of consequences of autoaggressive actions (they do not foresee the possibility of fatal outcome, lack clear discrimination between real suicide and intimidation-demonstrative action, which is at the same time life-threatening); secondly, suicidal motives are insignificant and unfounded; this complicates prevention of suicides; thirdly, suicidal attempts often do not depend on depression, which has latent character. Suicidal tendencies often have an important position in clinical presentation of children and adolescents with CP. They may be caused by loneliness, feeling of renunciation due to inability to play outdoor games, threat of losing parental love (birth of a second child, family composition change, death of parents); dissatisfaction with appearance, especially in case of pronounced visible deformations (gait distortion, hyperkinesiae of facial muscles), especially in girls. Demonstrative suicidal behavior aimed at punishing parents, offenders without an intention to kill oneself is observed in adolescents with hysteric and unstable personality traits; 
overprotective upbringing is conductive of such behavior. Despite the fact that these intentions are "ungrounded", such a behavior may in the end result in a suicide, unless help is rendered. People who have done suicidal acts before also belong to risk groups. Affective suicidal behavior - suicide due to extreme anxiety is primarily observed in emotionally labile adolescents, especially with hyperkinetic CP forms, and seems to be the most dangerous as sometimes it takes its course at narrowed consciousness. The worst defect experience is observed in adolescence, after graduating from residential school and when entering the circle of healthy peers. Postoperative period is also critical, as there often are no quick results that patients anticipate; they start feeling disappointed and hopeless, especially if they had waited for an operation for a long period of time; the waiting itself sometimes causes disturbance of vegetoreactions and a range of other functional changes in the body. In order to prevent suicides, personnel of specialized institutions should pay attention to early identification of psychogenic reactions connected with worrying about the patients' inferiority, suicidal thoughts given that most such patients ignore the defect. In order to resolve this issue it is recommended to reveal suicidal risk groups, organize a database of such patients, maintain regular home visits by a district pediatric psychiatrist to work with children with suicidal tendencies, conduct psychotherapy and attract doctors' attention to uncommonness of depression; it is necessary to hide suicide attempts from children, as children tend to be extremely suggestible and imitating [8].

Professional orientation should be conducted as soon as possible, as it allows developing motor and mental capabilities according to the chosen profession [8, 21, 32].

Early and thorough diagnostics of mental disorders at cerebral palsies, adequate and timely conduct of medical-psychological-pedagogic correctional measures, development of differentiated influence measures will allow preventing pathologic personality development in disabled children and improving complex rehabilitation effectiveness; this will help children's successful and effective social adaptation and integration.

\section{REFERENCES}

1. Nemkova S.A., Namazova-Baranova L.S., Maslova O.I. Detskii tserebral'nyi paralich: diagnostika i korrektsiya kognitivnykh narushenii: Uchebno-metodicheskoe posobie [Child Cerebral Palsy: Diagnosis and Correction of Cognitive Impairment. Study Guide]. Moscow, 2012. 56 p.

2. Lil'in E.T., Doskin V.A. Detskaya reabilitologiya [Children's Rehabilitation]. Moscow, Litterra. 2011, 630 p.

3. Nemkova S.A., Zavadenko N.N., Namazova-Baranova L.S. et al. Diagnostika i korrektsiya kognitivnykh rasstroistv u detei s tserebral'nym paralichom: Uchebno-metodicheskoe posobie [Diagnosis and Correction of Cognitive Disorders in Children with Cerebral Palsy. Study Guide]. Moscow, 2011. 32 p.

4. Ito J., Araki A., Tanaka H., Tasaki T., Cho K. Intellectual status of children with cerebral palsy after elementary education. Pediatric Rehabilitation. 1997; 1 (4): 199-206. 
5. Savina M.V. Mezhdunarodnyi meditsinskii zhurnal - International medical journal. 2010; 3. 6. Nemkova S.A., Maslova O.I., Zavadenko N.N., Karkashadze G.A. Detskaya i podrostkovaya reabilitatsiya - Child and adolescent rehabilitation. 2012; 1: 14-16.

7. Nemkova S.A., Maslova O.I., Karkashadze G.A. et al. Pediatricheskaya farmakologiya Pediatric pharmacology. 2012; 3.

8. Kalizhnyuk E.S. Psikhicheskie narusheniya pri detskikh tserebral'nykh paralichakh [Mental Disorders in Children with Cerebral Palsy]. Kiev, Vishcha shkola, 1987. 269 p.

9. Vasserman E.L., Katysheva M.V. Obozrenie psikhiatrii i meditsinskoi psikhologii im. V. M.

Bekhtereva - Bekhterev Review of psychiatry and medical psychology. 1998; 2: 45-52.

10. Nemkova S.A., Namazova-Baranova L.S., Maslova O.I., Zavadenko N.N., Kholin A.A., Karkashadze G.A., Mamed'yarov A.M., Nesterovskii Yu.E., Govorun S.V. Detskii tserebral'nyi paralich: diagnostika i korrektsiya kognitivnykh narushenii. Uchebno-metodicheskoe posobie [Child Cerebral Palsy: Diagnosis and Correction of Cognitive Impairment. Study Guide]. Moscow, Soyuz pediatrov Rossii, 2012. 60 p.

11. Kalizhnyuk E.S. Zhurn. nevrologii i psikhiatrii im. S.S. Korsakova - S.S. Korsakov journal of neurology and psychiatry. 1983; 83 (10): 1552-1556.

12. Levchenko I.Yu. Sistema psikhologicheskogo izucheniya lits s detskim tserebral'nym paralichom na raznykh etapakh sotsial'noi adaptatsii. Avtoref. dis. ... dokt. psikh. nauk [System Psychological Study of Individuals with Cerebral Palsy at Different Stages of Social Adaptation. Author's abstract]. Moscow, 2001.

13. Levchenko I.Yu., Prikhod'ko O.G. Tekhnologiya obucheniya i vospitaniya detei s narusheniyami oporno-dvigatel'nogo apparata [Technology of Training and Education of Children with Disorders of the Musculoskeletal System]. Moscow, 2001.

14. Baranov A.A., Klochkova O.A., Kurenkov A.L., Namazova-Baranova L.S., Nikitin S.S., Artemenko A.R., Mamed"yarov A.M. Pediatricheskaya farmakologiya - Pediatric pharmacology. 2012; 9 (6): 24-32.

15. Lebedev V. N. Narusheniya psikhicheskogo razvitiya u detei s tserebral'nymi paralichami [Psychic Disorders in Children with Cerebral Palsy]. Moscow, 1991.

16. Mamaichuk I.I. Psikhologiya dizontogeneza i osnovy psikhokorrektsii [Psychology of Disontogenesis and Foundations of Psychological Correction]. St. Petersburg, Izd-vo SpbGU, 2001. $158 \mathrm{p}$.

17. Mastyukova E.M. Deti s tserebral'nym paralichom. Spetsial'naya psikhologiya. Pod red. V.I. Lubovskogo [Children with Cerebral Palsy. Special Psychology. Edited by V.I. Lubovskii]. Moscow, 2003.

18. Poppandova M.Yu. Issledovanie nekotorykh gnostiko-praksicheskikh funktsii u detei, stradayushchikh tserebral'nym paralichom, v svyazi s zadachami vosstanovitel'noi terapii. Avtoref. dis. ...kand. med. nauk [Investigation of Some Gnostic and Practical Functions in Children with Cerebral Palsy, in Connection with Problems of Rehabilitation Therapy. Author's abstract]. Leningrad, 1971.

19. Kozyavkin V.I., Shestopalova L.F. Psikhologicheskoe obsledovanie detei s organicheskimi porazheniyami tsentral'noi nervnoi sistemy, $v$ tom chisle s detskimi tserebral'nymi paralichami: Metodicheskie rekomendatsii [Psychological Examination of Children with Organic Lesions of the Central Nervous System, Including those with Cerebral Palsy. Guidelines]. Khar'kov, 1995. $21 \mathrm{p}$.

20. Jenks K. M., de Moor J., van Lieshout E. C., Maathuis K. G., Keus I., Gorter J. W. The effect of cerebral palsy on arithmetic accuracy is mediated by working memory, intelligence, early numeracy, and instruction time. Developmental Neuropsychology. 2007; 32 (3): 861-79. 21. Maslova O.I. Dinamika klinicheskikh sindromov organicheskikh porazhenii nervnoi sistemy u detei pri dlitel'noi reabilitatsii. Avtoref. dis. ... dokt. med. nauk [Dynamics of Clinical Syndromes of Organic Lesions of the Nervous System in Children with Long-term Rehabilitation. Author's abstract]. Moscow, 1992. 
22. Mamaichuk I.I., Umkhanov Kh.A. Ortopediya, travmatologiya i protezirovanie Orthopedics, Traumatology and Prosthetics. 1986; 11: 58-61.

23. Lavrent'eva A.N. Sotsial'no-bytovaya adaptatsiya detei s tserebral'nymi paralichami $v$ usloviyakh reabilitatsionnogo uchrezhdeniya. Avtoref. dis. ... kand. ped. nauk [Social Adaptation of Children with Cerebral Palsy in a Rehabilitation Facility. Author’s abstract]. Yakutsk, 2002. 23 p.

24. Baranov A.A., Maslova O.I., Namazova-Baranova L.S. Vestnik Rossiiskoi akademii meditsinskikh nauk - Annals of the RAMS. 2012; 8: 26-33.

25. Mastyukova E. M. Osobennosti lichnosti uchashchikhsya s tserebral'nym paralichom. Osobennosti psikhofizicheskogo razvitiya uchashchikhsya spetsial'nykh shkol dlya detei s narusheniyam oporno-dvigatel'nogo apparata. Pod red. T.A. Vlasovoi [Features Personality of Students with Cerebral Palsy. Special Needs of Students in Special Schools for Children with Disorders of the Musculoskeletal System. Edited by T.A. Vlasova] Moscow, Pedagogika, 1985. pp. 70-89.

26. Kirichenko E.I. Zhurn. nevrologii i psikhiatrii im. S.S. Korsakova - S.S. Korsakov journal of neurology and psychiatry. 1983; 9: 1390-1394.

27. Kalizhnyuk E.S. Zhurn. nevrologii i psikhiatrii im. S.S. Korsakova - S.S. Korsakov journal of neurology and psychiatry. 1985; 3.

28. Tyurin A.V. Psikhologicheskaya adaptatsiya invalidov s posledstviyami detskogo tserebral'nogo paralicha. Avtoref. dis. ...kand. psikh. nauk [Psychological Adaptation of Disabled Coping with the Consequences of Cerebral Palsy. Author's abstract]. Moscow, 2000. 26 p.

29. Ramenskaya O.L. Psikhologicheskoe issledovanie lichnosti doshkol'nikov s tserebral'nym paralichom. Avtoref. dis....kand. med. nauk [Psychological Study of Personality of Preschool Children with Cerebral Palsy. Author's abstract]. Moscow, 1979. 23 p.

30. Ippolitova M.V., Chernobrovkina E.D. Pedagogam i vospitatelyam o detyakh s otkloneniyami v razvitii. Metodicheskoe posobie [For Teachers and Tutors of Children with Developmental Disabilities. Manual]. Moscow, IKP RAE, 1994. 80 p.

31. Levchenko I.Yu., Kuznetsova G.V. Osnovnye printsipy i metody korrektsionnopedagogicheskoi raboty s det'mi, stradayushchimi detskim tserebral'nym paralichom. Medikosotsial'naya reabilitatsiya bol'nykh i invalidov vsledstvie detskogo tserebral'nogo paralicha [Basic Principles and Methods of Correction and Pedagogical Work with Children Suffering from Cerebral Palsy. Medical and Social Rehabilitation of the Sick and Disabled as a Result of Cerebral Palsy]. Moscow, 1991.

32. Kryzhko E.V. Lichnostno-orientirovannaya psikhologicheskaya korrektsiya podrostkov s tserebral'nym paralichom. Avtoref. dis. ...kand. med. nauk [Person-oriented Psychological Adjustment of Adolescents with Cerebral Palsy. Author's abstract]. St. Petersburg, 2009. 33. Fadeeva E.V. Vliyanie dvigatel'noi patologii na lichnostnoe razvitie podrostkov s tserebral'nym paralichom. Avtoref. dis....kand. med. nauk [Influence of Motor Pathology on the Personal Development of Young People with Cerebral Palsy. Author's abstract]. Nigny Novgorod, 2010.

34. Prikhod'ko O.G. Sistema rannei kompleksnoi differentsirovannoi korrektsionnorazvivayushchei pomoshchi detyam s tserebral'nym paralichom. Avtoref. dis. ...kand. med. nauk [System of Early Integrated Differential Correction and Developmental Assistance to Children with Cerebral Palsy. Author's abstract]. Moscow, 2009.

35. Nemkova S.A., Kobrin V.I., Sologubov E.G. et al. Nevrologicheskii zhurnal - Journal of neurology. 2000; 2: 20-24.

36. Levchenko I.Yu., Pavlovskaya N.T. Korrektsionnaya pedagogika - Correctional pedagogics. 2006; 2 (14): 5-12.

37. Arkhipova E.F. Korrektsionnaya rabota s det'mi s tserebral'nym paralichom [Correctional Work in Children with Cerebral Palsy]. Moscow, Prosveshchenie, 1989. 77 p. 
38. Nemkova S.A., Maslova O.I., Zavadenko N.N. Sotsial'naya pediatriya i reabilitologiya Social pediatrics and rehabilitation. 2012; 1.

39. Nemkova S. A., Maslova O. I., Zavadenko N. N. The use of space technologies for the rehabilitation of the cognitive disorders in children with cerebral palsy. Europaediatrics-2011. Viena. 2011.

40. Semenova K.A. Vosstanovitel'noe lechenie detei s perinatal'nym porazheniem nervnoi sistemy i detskim tserebral'nym paralichom [Rehabilitation Treatment of Children with Perinatal Lesions of the Nervous System and Cerebral Palsy]. Moscow, Kodeks, 2007. 616 p.

41. Tselevich T.I. Sotsial'no-pedagogicheskoe soprovozhdenie sem'i, vospityvayushchei rebenka s tyazhelymi formami tserebral'nogo paralicha na etape ego podgotovki k shkol'nomu obucheniyu. Avtoref. dis. ... kand. ped. nauk [Social and Educational Support for Families Raising a Child with Severe Cerebral Palsy at the Stage of Preparation for School. Author's abstract] Omsk, 2008.

42. Ispol'zovanie preparatov botulotoksina A v kompleksnoi reabilitatsii detei s narusheniyami oporno-dvigatel'nogo apparata. Posobie dlya vrachei. Pod red. E.T. Lil'ina [The Use of Botulinum toxin A Medicines in the Complex Rehabilitation of Children with Disorders of the Musculoskeletal System. Manual for Physicians. Edited by E.T. Lil'in]. Moscow, 2008. 96 p. 43. Klochkova O.A., Kurenkov A.L., Namazova-Baranova L.S., Mamed"yarov A.M. Rannii opyt primeneniya botulinoterapii u detei so spasticheskimi formami DTsP s porazheniem verkhnikh konechnostei [Early Experience of Botulin Therapy in Children with Spastic Cerebral Palsy Forms with the Final Defeat of the Upper Limbs]. II ezhegodnaya mezhdistsiplinarnaya nauchno-prakticheskaya konferentsiya s mezhdunarodnym uchastiem «Detskii tserebral'nyi paralich i drugie narusheniya dvizheniya u detei» 15-16 noyabrya 2012 goda. Materialy konferentsii ( $2^{\text {nd }}$ Annual Interdisciplinary Scientific and Practical Conference with International Participation "Cerebral Palsy and other Movement Disorders in Children" on November 15-16, 2012. Proceedings of the Conference). pp. 83-84. 